\title{
Hemşirelik Öğrencilerinin Doğuma İlişkin Algıları: Nitel Bir Çalışma*
}

\author{
Nevin ÇITAK BILGIIN 國
}

\section{ÖZ}

Amaç: $\mathrm{Bu}$ çalışma hemşirelik bölümünde öğrenim gören öğrencilerin doğuma ilişkin algılarını belirlemek için yapılmıştır.

Gereç ve Yöntemler: Nitel tipteki araştırma Batı Karadeniz Bölgesi'ndeki bir ilde yer alan bir üniversitenin hemşirelik bölümünde öğrenim gören 37 öğrenci ile gerçekleştirilmiştir. Veriler kişisel bilgi formu ve yarı yapılandırılmış görüşme formu kullanılarak toplanmıştır. Veriler içerik analizi ile değerlendirilmiştir.

Bulgular: Öğrencilerin yaş ortalaması 20,56 $\pm 1,55$ olup, \%43,2'si kadın-doğum dersi almış ve \%35,1'i eğitim sürecinde doğum gözlemlemiştir. İçerik analizi sonucunda doğum algisı ile ilgili iki tema, beş alt tema ve bu alt temalara ilişkin 24 kod belirlenmiştir. İlk tema doğuma bakış olup, bu tema altında; olumlu bakış, olumsuz bakış ve spiritüel bakış olarak 3 alt tema belirlenmiştir. İkinci tema doğum tercihi olup, bu tema altında tercih edilen doğum şekli ve tercihi belirleyenler olarak iki alt tema ortaya çıkmıştır. Doğuma olumlu bakış altında; öğrencilerin çoğunun doğumu heyecan ve mutluluk verici bir durum olarak değerlendirdikleri belirlenmiștir. Spiritüel bakıș açısı ile, doğumu yeni bir hayatın başlangıcı olarak gördükleri saptanmıştır. Öğrenciler doğuma ilişkin olumsuz görüşlerini en çok acı- zorluk şeklinde ifade etmişlerdir. Öğrencilerin en fazla normal doğumu tercih ettiği, doğum tercihini belirleyici olarak en çok ifade edilen görüşün ise fiziksel iyilik hali ile ilgili olduğu bulunmuştur.

Sonuç: Hemşirelik öğrencilerinin doğuma ilişkin algılarının olumlu olduğu, normal doğumu tercih ettikleri ve doğum tercihini belirlemede fiziksel, psiko-sosyal ve spiritüel iyilik halinin önemli olduğu saptanmıştır.

Anahtar Kelimeler: Doğum; alg1; hemşirelik; nitel araştırma.

\section{Nursing Students' Perceptions of Birth: A Qualitative Study}

\begin{abstract}
Aim: This study was carried out to determine the birth perception of nursing department students.

Material and Methods: Qualitative research was carried out with 37 students studying in nursing department of the university in a province in western Black Sea Region. The data were collected by using personal information form and semi-structured interview form. The data were evaluated by content analysis.

Results: The average age of the students was $20.56 \pm 1.55,43.2 \%$ of them took obstetrics and gynecology, $35.1 \%$ of them observed the birth process within the scope of education. After the content analysis, two themes, five sub-themes and 24 codes related to these sub-themes were determined. The first theme is the view of birth and under this theme; 3 sub-themes are identified as positive, negative and spiritual view. The second theme is the birth preference, and under this theme two sub-themes have emerged as the preferred type of delivery and the factors that determine the preference. As positive view to birth; most of the students considered birth as an exciting and happy situation. From a spiritual point of view, they regarded birth as the beginning of a new life. The students expressed their negative opinions about birth mostly as pain and difficulty. The students preferred normal birth the most, and the mostly expressed opinion
\end{abstract}

\footnotetext{
1 Bolu Abant İzzet Baysal Üniversitesi Sağlık Bilimleri Fakültesi, Hemşirelik Bölümü, Doğum Kadın Sağlığı ve Hastalıkları Hemşireliği Anabilim Dalı, Bolu, Türkiye

*Bu çalışma, 20-23 Şubat 2020 tarihleri arasında Bolu'da düzenlenen 4. Uluslararası Gebelik Doğum ve Lohusalık Kongresi'nde sözlü bildiri olarak sunulmuştur.
}

Sorumlu Yazar / Corresponding Author: Nevin CITAK BiLGIN, e-mail: nevincitak@yahoo.com Geliş Tarihi / Received: 10.04.2020, Kabul Tarihi / Accepted: 01.09.2020 
determining the birth preference was related to the physical well-being.

Conclusion: Nursing students' perceptions about birth were positive, they preferred normal birth and physical, psycho-social and spiritual well-being were important in determining their birth preferences.

Keywords: Birth; perception; nursing; qualitative research.

\section{GİIS}

Gebelik ve doğum insan yaşamında çok yönlü ve eşsiz bir deneyim olarak görülse de (1), biyo-psikososyal dengenin ve rollerinin değiştiği ve bu rollere uyumda güçlük yaşanan bir kriz dönemi de olabilmektedir (2). Doğuma ilişkin alg1 bireylerin doğuma ilişkin hislerini, düşüncelerini, doğumla ilgili kendisini, çevresini ve sağlık personelini nasıl değerlendirdiğini tanımlar ve bireylere göre farklılık gösterir (3). Doğum algısı kişilik özellikleri ve sosyo-kültürel faktörler ile ilişkilidir. Yapılan çalışmalarda, doğumla ilgili bilgi eksikliği, önceki olumsuz deneyimler, sosyal destek sistemlerinin yetersizliği, ağrı yaşama, bebeğin sağlı̆̆1, cinsel yaşam ve sağlık ekibinin yaklaşımlarına ilişkin endişelerin doğum algısını ve buna bağlı olarak da doğum tercihlerini etkilediği bilinmektedir (4-6).

Çalışmalar doğuma ilişkin olumsuz alg1 ve korkunun maternal ve fetal sağlığı etkilediğini, doğum memnuniyetini azalttığını ve elektif sezaryen tercihini artırdığını ortaya koymaktadır $(7,8)$. Günümüzde hem gelişmiş hem de gelişmekte olan ülkelerde sezaryen doğum oranları, Dünya Sağlık Örgütü tarafından tavsiye edilen ideal sezeyan oranı \% 15 'in üzerindedir (9). Ülkemizde de tüm dünyada olduğu gibi son yıllarda sezaryen oranlarındaki artış dikkat çekici olup, Türkiye'nin 2015 yılında OECD ülkeleri arasında sezaryen doğum oranında birinci sırada yer aldığ görülmektedir (10). Türkiye Nüfus ve Sağlık Araştırması'na (11) göre ülkemizde sezaryen oranı 2008 y1lında \%36,7 iken, 2018 yılında \%52'ye yükselmiş ve gebelerin \%38'inde sezaryen kararı doğum sancıları başlamadan önce alınmıştır. Sezaryen doğumlar maternal mortalite ve morbiditeyi artırmakta olup, özellikle herhangi bir endikasyon olmaksızın isteğe bağl1 gerçekleşen sezaryenler üreme sağlığını olumsuz yönde etkilemektedir $(9,12)$.

Literatürde doğum tercihleri, doğuma ilişkin görüş ve düşünceleri belirlemeye yönelik çalışmalar çoğunlukla gebe kadınlar ve eşlerine yöneliktir (4,13-15). Oysaki yapılan çalışmalar geleceğin anne ve baba adayı olan üniversite öğrencilerinin doğuma ilişkin bilgilerinin yetersiz olduğunu $(16,17)$, doğuma yönelik korku ve endişelerinin olduğunu $(3,18,19)$, doğumu riskli olarak algıladıklarını ve özellikle vajinal doğumu korkutucu ve kayg1 verici bulduklarını göstermektedir $(18,20)$. Elektif sezaryenin son y1llarda vajinal doğuma alternatif olarak sunulması (21), doğumda yapılan müdahaleler ve girişimlerin bir sorun olarak görülmemesi $(17,18)$, doğumda ağrı/acı yaşama ve kontrolü kaybetme korkusu $(22,23)$ ve vajinal doğum hakkındaki olumsuz inançlar ve özgüven eksikliği (24) üniversite öğrencilerinin sezaryen doğum tercihi ile ilişkili görülmektedir.

Gerek uluslararası ve gerekse ulusal yazında üniversite öğrencilerinin doğum tercihlerini, doğuma ilişkin inanç ve tutumları belirlemeye yönelik daha çok son 10 yılda yapılmış araştırmalar olsa da (17,21,22,24-27), öğrencilerin konuya ilişkin görüşlerinin daha ayrıntılı incelenmesine olanak sağlayan nitel çalışmalar oldukça sınırlıdır $(3,16,20)$. Öğrencilerin doğuma ilişkin algılarının, doğum tercihlerinin ve bu tercihleri etkileyen faktörlerin belirlenmesi; gençlerin üreme sağlığını korumak ve geliştirmek, daha bilinçli ebeveynler olmalarına katkı sağlayabilir (16).

Sağlık ekibinin önemli bir parçası olan hemşire öğrencilerin doğuma yönelik olumlu algıya sahip olmaları, gerek kendileri ve partnerleri, gerekse hizmet verdikleri bireyler açısından doğum tercihlerini daha bilinçli yapmaları ve normal doğum için motivasyonun sağlanması açısından önemlidir. Öğrencilerin doğum ile ilgili farkındalıklarının artması, aynı zamanda gebeleri ve yakınlarını antenatal dönemde ve doğum sürecinde uygun şekilde destekleyebilmeleri ve etkili müdahalelerde bulunabilmeleri için de önemlidir. Bu bilgiler 1şı̆̆ında çalışma hemşirelik bölümünde öğrenim gören üniversite öğrencilerinin doğuma algılarını belirlemek amacıyla yapılmıştır.

\section{GEREÇ VE YÖNTEMLER}

\section{Araştırmanın Tipi}

$\mathrm{Bu}$ çalışma nitel araştırma deseninde yapılmıştır.

\section{Katılımcilar}

Araştırmanın çalışma grubunu Batı Karadeniz Bölgesi'nde yer alan bir ilde sağlık yüksekokulu hemşirelik bölümünde öğrenim gören 37 öğrenci oluşturmuştur. Kavramlar ve süreçlerin tekrar etmeye başladığı doyum noktasına kadar veri toplanmaya devam edilmiş ve 37 öğrenci ile veri doygunluğuna ulaşılmıştır. Araştırmada amaçlı örnekleme yöntemlerinden biri olan maksimum çeşitlilik örnekleme yöntemi kullanılmıştır.

\section{Veri toplama araçları}

Veriler kişisel bilgi formu, yarı yapılandırılmış görüşme formu ve görüşmeci gözlem formu ile toplanmıştır.

Kişisel bilgi formu: $\mathrm{Bu}$ form öğrencilerin yaş, cinsiyet, öğrenim gördükleri sınıf, anne eğitim düzeyi, kardeş sayısı gibi sosyo-demografik özellikler ile, kadın-doğum dersi alma, doğuma ilişkin gözlem yapma durumunu içeren sorulardan oluşmuştur.

Yarı yapılandırılmış görüsşme formu ve görüşmeci gözlem formu: Yarı yapılandırılmış görüşme formu, öğrencilerin doğuma ilişkin algılarını ve doğum tercihlerini belirlemek için araştırmacı tarafindan literatüre göre hazırlanmıştır. Buna göre öğrencilere;

- Doğum deyince aklınıza ilk olarak neler geliyor, anlatır misinız?

- Kendiniz ya da eşiniz için hangi doğum şeklini tercih edersiniz?

- Kendiniz ya da eşiniz için neden bu doğum şeklini tercih ettiğinizi anlatır misınız? soruları yöneltilmiştir. Görüşmeci gözlem formunda ise, görüşülen her bir katılımcıyı gösteren kod numarası (K1, $\mathrm{K} 2$, K3...), görüşme tarihi ve saati gibi bilgiler yer almıştır.

\section{Verilerin Toplanması}

Araştırma verileri toplanmadan önce öğrenciler çalışma hakkında bilgilendirilerek, çalışmaya katılmak isteyen öğrencilerden yazılı onamları alınmıştır. Veriler KasımAralık 2017 tarihleri arasında toplanmıştır. Görüşmeler 
araştırmacı tarafından katılımcı ile yalnız olarak özel bir odada gerçekleştirilmiştir. Her bir öğrenciye isimleri kullanılmadan analiz kolaylığı açısından kod adı verilmiştir (K1,K2,...K37). Görüşmenin başında kişisel bilgi formu yüz yüze görüşme yöntemi ile doldurulmuştur. Dört öğrenci ile ön uygulama yapılmıştır. Ön uygulama sonrası veriler incelenerek soruların anlaşılır olduğu görülmüş ve değişiklik yapılmadan çalışmaya devam edilmiştir. Ön uygulama verileri araştırmaya dahil edilmiştir. Görüşmeler her bir katılımcı için 15-45 dakika sürmüştür. Görüşmelerde zaman kaybını önlemek ve analizlerin daha sağlıklı yapılabilmesi için ses kaydı yapılmak istendiği ve öğrencilere istedikleri anda ses kaydının kapatılabileceği açıklanmıştır. Ayrıca öğrencilere ses kaydını yalnızca araştırmacının dinleyeceği, başka kişilerle paylaşılmayacağı söylenmiştir. $\mathrm{Bu}$ koşulları kabul eden öğrenciler ile yapılan görüşmeler ses kayıt cihazına kaydedilmiştir. Veri doygunluğuna ulaşılıncaya kadar veriler toplanmıştır.

\section{Araştırmanın Etik Yönü}

Çalışmanın yapılabilmesi için Sosyal Bilimler İnsan Araştirmaları Etik Kurul'undan (tarih: 2017, sayı no:249) ve çalışmanın yürütüldüğü kurumdan (tarih: 2017, sayı no:56562) izin alınmıştır. Öğrencilere çalışmanın amaçları açıklanmış, çalışmaya katılımın gönüllülük ilkesi ile olacağı, çalışmadan elde edilen bilgilerin gizli tutulacağı, yalnızca bu çalışma için kullanılacağı ve istedikleri zaman çalışmadan ayrılabilecekleri konusunda bilgilendirilme yapılmış ve Helsinki Bildirgesi ve yayın etiğine uyulmuştur. Çalışmaya katılmayı kabul eden öğrencilerden sözlü ve yazılı onam alınmıştır.

\section{İstatistiksel Analiz}

Veriler içerik analizi kullanılarak çözümlenmiştir. Görüşmeler tamamlandıktan sonra ses kayıtları ve görüşme esnasında alınan notlar araştırmacı tarafından bilgisayara aktarılmıştır. Ses kayıtları dinlendikten sonra ham veriler yazılı metne dönüştürülmüştür. Araştırmanın amacı doğrultusunda yazılı metin bir çok kez okunarak veriler kodlanmıştır. Oluşturulan kodlar anlam bütünlüğüne göre gruplandırıldıktan sonra bu kodları temsil edecek tema isimleri oluşturulmuştur. Öğrencilerin tanıtıcı özellikleri sayı, yüzde, ortalama, standart sapma ile değerlendirilmiştir.

\section{BULGULAR}

Öğrencilerin tanımlayıcı özellikleri Tablo 1'de gösterilmiştir. Öğrencilerin yaş ortalaması $20,56 \pm 1,55$ olup, \% 48,6'sı kadın, \% 51,4'ü erkektir. Katılımcıların \% 29,7'si birinci ve ikinci sınıfta öğrenim görmektedir. Öğrencilerin \% 73,0'ının anneleri ilköğretim ve altı öğrenim düzeyine sahip olup \% 59,5'inin üç ve üzeri kardeş olduğu görülmüştür. Öğrencilerin \% 43,2'sinin kadın-doğum dersi aldığı, \% 35,1'inin doğum gözlemlediği ve gözlem yapanların 2/3'ünün hem vajinal hem de sezaryen doğumu izlediği belirlenmiştir.

Yapılan içerik analizi sonucunda doğum algısı ile ilgili iki tema, beş alt tema ve bu alt temalara ilişkin 24 kod belirlenmiştir.

\section{Tema I. Doğuma Bakış}

İlk tema doğuma bakış olup, bu tema altında; olumlu bakış, olumsuz bakış ve spiritüel bakış olarak üç alt tema belirlenmiştir. Olumlu bakış temasına ilişkin altı kod (mutluluk, yeni birey, fizyolojik süreç, aile olma, fedakarlık, cesaret), olumsuz bakış temasına ilişkin üç kod (acı, korku, ağrı) ve spiritüel bakışa ilişkin üç kod (yeni bir hayat, mucize, kutsallık) olmak üzere toplam 12 kod belirlenmiştir.

Tablo 1. Öğrencilerin tanımlayıcı özelliklerine göre dağılımı

\begin{tabular}{|c|c|c|}
\hline$\overline{\text { Özellik }}$ & $\begin{array}{l}\text { Sayı } \\
\text { /Ortalama }\end{array}$ & $\overline{\%}$ \\
\hline Yaş $(\mathrm{y} 11)(\mathrm{Ort} \pm \mathrm{SD})$ & $\begin{array}{l}20.56 \\
\pm 1.55\end{array}$ & $\begin{array}{l}(\text { range }=18- \\
24)\end{array}$ \\
\hline \multicolumn{3}{|l|}{ Cinsiyet } \\
\hline Kadın & 18 & 48,6 \\
\hline Erkek & 19 & 51,4 \\
\hline \multicolumn{3}{|l|}{ Sinıf } \\
\hline 1. Sinif & 11 & 29,7 \\
\hline 2. Sinif & 11 & 29,7 \\
\hline 3. Sinif & 8 & 21,7 \\
\hline 4. Sinif & 7 & 18,9 \\
\hline \multicolumn{3}{|l|}{ Anne Öğrenim Durumu } \\
\hline İlköğretim ve altı & 30 & 73,0 \\
\hline Lise ve üzeri & 10 & 27,0 \\
\hline \multicolumn{3}{|l|}{ Kardeş Sayısı } \\
\hline Tek çocuk & 2 & 5,4 \\
\hline İki kardeş & 12 & 35,1 \\
\hline Üç kardeş ve üzeri & 22 & 59,5 \\
\hline \multicolumn{3}{|l|}{$\begin{array}{l}\text { Kadın-Doğum Dersi Alma } \\
\text { Durumu }\end{array}$} \\
\hline Evet & 16 & 43,2 \\
\hline Hayır & 21 & 56,8 \\
\hline \multicolumn{3}{|l|}{ Doğum Gözlemi } \\
\hline Evet & 13 & 35,1 \\
\hline Hayır & 24 & 64,9 \\
\hline $\begin{array}{lll}\begin{array}{l}\text { Gözlenen } \\
(n=13)\end{array} & \text { Doğum } & \text { Şekli } \\
\end{array}$ & & \\
\hline Vajinal & 1 & 7,7 \\
\hline Sezaryen & 2 & 15,4 \\
\hline Vajinal+Sezaryen & 10 & 76,9 \\
\hline
\end{tabular}

\section{Alt Tema 1: Olumlu Bakıș}

Katılımcıların doğuma olumlu bakış olarak çoğunun doğumu heyecan ve mutluluk verici $(n=25)$ bir durum olarak değerlendirdikleri görülmüştür. $\mathrm{Bu}$ konudaki düşüncelerini katılımcılar;

"Doğum sadece bebek değil onunla birlikte sevinci, mutluluğu, heyecanı, tatlılı̆̆ barındıran bir beraberliktir. Doğumun yuvayı şenlendirdiğine inanıorum” (K5, kadın).

"Mutluluk, kutlama, bayram havasi gibi doğum. Çünkü kardeşim doğduğunda sanki bayram gelmiş gibiydi ortam..." (K29, erkek), şeklinde ifade etmiştir.

Doğumun anlamına ilişkin en fazla ifade edilen diğer kavram ise bebek /yeni bir bireyin dünyaya gelişi $(n=16)$ olup, erkek öğrenciler bu konuda daha fazla görüş bildirmiştir. Öğrenciler bu konudaki düşüncelerini

"Doğum deyince, yardıma muhtaç, sevgi ve şefkat bekleyen minik bir beden geliyor aklıma" (K8, erkek). 
“....bir canlının dünyaya gelişi, ilk defa gözlerini açması yaşam adına ilk adımını atması” (K36, erkek).

"Küçücük bir can..." ( K25, kadın), olarak belirtmiştir.

Tablo 2. Öğrencilere göre doğumun anlamı

\begin{tabular}{llc}
\hline $\begin{array}{l}\text { Tema I, Doğuma } \\
\text { Bakış }\end{array}$ & \\
\hline Alt Tema 1: & Olumlu Bakış & $\mathbf{n}^{*}$ \\
\hline & Heyecan ve & 25 \\
& mutluluk & \\
Bebek-yeni birey & 16 \\
Kod & Fizyolojik süreç & 10 \\
& Ebeveyn-aile olma & 10 \\
& Fedakarlık- & 7 \\
& sorumluluk & \\
& Güç ve cesaret & 6 \\
\hline Alt Tema 2: & Olumsuz Bakış & $\mathbf{n}$ \\
\hline \multirow{3}{*}{ Kod } & Acı-zorluk & 10 \\
& Korku ve endişe & 9 \\
\hline Alt Tema 3: & Ağrı -sancı & 9 \\
\hline & Spiritüel Bakıș & $\mathbf{n}^{*}$ \\
\hline \multirow{2}{*}{ Kod } & Yeni bir hayat/ & 18 \\
& hayatın başlangıcı & \\
\hline * & Mucize & 15 \\
\hline
\end{tabular}

*n katlanmıştır

Öğrencilerin bazılarının doğumu fizyolojik bir süreç $(n=10)$ ve ebeveyn/aile olma süreci $(n=10)$ olarak değerlendirdiği görülmüştür. Doğumun fizyolojik bir süreç olduğunu düşünen öğrenciler bu konudaki görüşlerini;

"Doğum tamamen fizyolojik bir süreç olup, doğal sancularla başlayıp bebeğin anneye ve kendisine zarar vermeden vajinal yoldan diş dünyaya açılmasıdır....." (K4, kadın).

"....doğum üremek için gerekli fizyolojik bir süreç aynı zamanda” (K30, erkek).

"Doğum neslin devamını sağlamak için gereklidir. Spermin yumurtayı dölledikten sonra zigot oluşumundan sonra geçen normal doğum için 9 ay 10 gün gerektiren bir süreçtir" (K34, erkek), şeklinde ifade etmiştir.

Doğumu aynı zamanda ebeveyn/aile olma süreci $(n=10)$ olarak değerlendirilmiş öğrenciler bu görüşlerini;

"Doğum bir kadının anneliğe bir erkeğin babalı̆̆a adımıdır” (K3, kadın).

“....aile olma tecrübesi” (K36, erkek).

“....ailenin büyümesi güçlenmesi” (K22, erkek), diye tanımlamıştır.

Doğumu fedakarlık ve sorumluluk olarak tanımlayanlardan $(\mathrm{N}=7)$ bir öğrenci görüşünü

“...bu işin ucunda bir insan var ve bu insan senin birebir canından kanından, herkesten önemli ....bu da büyük sorumluluk demek..." (K5, kadın) diye açıklarken,

Doğumu güç ve cesaret olarak ifade eden $(\mathrm{N}=6)$ öğrencilerden biri de düşüncesini

"Doğum bir güç. Güç derken şunu kastediyorum: Annenin bebeğini gördüğ̈̈ anda o mutluluk yaşlarını dökerken hissettiği, bebeğini her zaman, her koşulda koruyabileceğine inandiğl, bunu içinin derinlerinde hissettiği delicesine güç" (K4, kadın) şeklinde açıklamıştır.

\section{Alt Tema 2: Olumsuz Bakış}

Öğrenciler doğuma ilişkin olumsuz görüşlerini en çok ac1zorluk $(n=10)$ ile korku-endişe $(n=9)$ ve ağrı-sancı $(n=9)$ yaşama şeklinde ifade etmişlerdir.

Doğumu acı ve zorluk yaşama olarak değerlendiren öğrenciler bu görüşlerini

“...doğum deyince zorluk ve acı da geliyor aklıma. Çünkü çevremde "ölümden döndüm, çok zordu” diyenleri gördüm..." (K6, kadın).

"Doğumhanenin içinde çı̆̆lık çı̆̆lı̆̆a bağıran, acı çeken bir hanım aklıma geliyor" (K10, erkek).

“......bir kadının doğururken canının çok yandığını düşünüyorum. Doğumun fizyolojik, psikolojik zor bir eylem olduğunu düşünüyorum" (K 14, kadın) diye ifade etmiştir

Doğumu korku ve endişe veren bir durum olarak ifade eden katılımcılardan bazılarının düșünceleri;

"Doğum tabiki de çok güzel bir şey ama beni korkutuyor” (K10,erkek ),

"Doğum deyince korku, çı̆̆lık, telaş geliyor" (K12, kadin).

"Doğum ürkütücü ve korkunç geliyor bana... Annemin doğumu hatırliyorum riskli bir doğumdu annemin $\mathrm{ki}$ beş hastane dolaştı ve doğum hakkında benimde bu sebepten korkularım var..." ( K23, kadın) şeklinde iken;

Doğumu ağrı ve sancı çekmek olarak değerlendiren öğrenciler görüşlerini;

"Çevremizden duyduklarım kadarlyla çok ăgrılı bir süreç olduğunu tahmin ediyorum” (K14, kadin).

"Kadınlar için ağrilı sancilı süren bir şey demek bence doğum" (K18, erkek) diye belirtmiştir.

\section{Alt Tema 3: Spiritüel Bakıs}

Öğrencilerin doğumu aynı zamanda spiritüel bakış açısı ile değerlendirdikleri saptanmıştır. Doğumun yeni bir hayat/hayatın başlangıcı olduğuna ilişkin görüşlerini

"Doğum tertemiz bir sayfa.....yeni bir hayat düzeni ve yepyeni başlangıçlar demektir” (K2, kadin).

"Insanın kendi ruhunu başka bedende dünyada yaşatmaya çalışması" (K20, erkek), şeklinde ifade etmişlerdir.

Doğumun spiritüel yönüne ilişkin en fazla ifade edilen diğer görüş ise doğumun bir mucize olduğudur. Öğrenciler bu düşüncelerini;

"Bir canll var ve o canliyl dokuz ay karnında taşlyıp bir gün onun dünyaya gelmesine aract oluyorsun. Doğum en mucizevi, en sıra dlşı şey bana göre......" (K1, kadın).

“....bir insanin bu dünyaya geldiğine şahit olmak, o ana tanıklık etmek kadar, doğum kadar mucizevi bir şey daha olduğunu sanmıyorum" ( $\mathrm{K} 11$, erkek).

"...Anne karninda hayat bulan; aslinda doğumla başlayıp, ölene kadar sürecek olan bir mucize! Belki de hayatım tam da burada değişecektir" (K25, kadın), şeklinde dile getirmişlerdir. 
Özellikle erkek öğrenciler tarafından doğumun kutsallığına vurgu yapılmıştır.

Bir katılımc1 düşüncesini "Doğum cennet kokusudur" (K3, kadın) diye ifade ederken diğer bazı katılımcilar,

"Nedendir bilmiyorum fakat doğum yapan kadın bana kutsal geliyor, ruhani bir varlık gibi görüyorum onlarl" (K8, erkek)

"Yüce Yaratıcının biz insanların çoğalması için cinsiyet bakımından kadınlara vermiş olduğu en kutsal şey bence" (K 35, erkek) diye ifade etmişlerdir.

\section{Tema II. Doğum Tercihi}

İkinci tema doğum tercihi olup, bu tema altında tercih edilen doğum şekli ve tercihi belirleyenler olarak iki alt tema belirlenmiştir (Tablo 3).

Tablo 3. Öğrencilerin doğum tercihleri ve tercihi etkileyenler

\begin{tabular}{llc}
\hline \multicolumn{2}{l}{ Tema II, Doğum tercihi } & \\
\hline Alt Tema 1: & Tercih Edilen Doğum & n \\
& Şekli & \\
\hline \multirow{2}{*}{ Kod } & Normal doğum & 30 \\
& Sezaryen & 5 \\
& Kararsız & 2 \\
\hline Alt Tema 2: & Tercihi Belirleyenler & $\mathbf{n}^{*}$ \\
\hline \multirow{4}{*}{ Kod } & Fiziksel iyi oluş & 27 \\
& Algılanan risk-yarar & 22 \\
& İnsan doğasına & 20 \\
& uygunluk & \\
& Kültürel etki, gözlem ve & 15 \\
& duyumlar & 15 \\
& Ağrı & 13 \\
& Beden imgesi ve beden & \\
& bütünlüğü & 11 \\
& Spiritüel iyi oluş & 9 \\
& Psikolojik iyi oluş- & \\
& bağlanma & \\
& Anı yaşamak-anda oluş &
\end{tabular}

\section{Alt Tema 1: Tercih Edilen Doğum Şekli}

Yürütülen çalışmada öğrencilerin en fazla $(n=30)$ normal doğumu tercih ettiği $\left(\operatorname{Kad}_{1}=13, \quad\right.$ Erkek=17), beş öğrencinin $\mathrm{S} / \mathrm{C}$ doğumu tercih ederken (Kadın=3, Erkek=2), iki kadın öğrencinin de doğum şekli konusunda kararsızlık yaşadığı görülmüştür.

\section{Alt Tema 2: Tercihi Belirleyenler}

$\mathrm{Bu}$ tema altında dokuz kod (fiziksel iyi oluş, algılanan risk-yarar, insan doğasına uygunluk, kültürel etki, ağr1, beden imgesi, spiritüel iyi oluş, psikolojik iyi oluş, anı yaşamak) belirlenmiştir. Öğrencilerin kendileri ya da partnerleri için doğum tercihini belirlemede en fazla ifade edilen görüş fiziksel iyilik hali $(n=27)$ ile ilgilidir.

Normal doğum tercih eden katılımcılar fiziksel iyilik hali ile ilgili olarak görüşlerini;

“..... normal doğumda doğumdan kısa süre sonra anne hayatına geri dönebilir ve bebeğiyle daha rahat ilgilenebilir" (K9, erkek).

"Vajinal doğumda doğum sonrast toparlanma süreci, sezaryene göre anne için daha hızlı...vajinal doğum daha mantıkl geliyor bana " (K32, kadın), diye ifade ederken
$\mathrm{S} / \mathrm{C}$ doğum tercih eden bir katılimc ise düşüncesini "....sezaryende annenin toparlanması daha kolay bence" (K 19, erkek), diye ifade etmiştir.

Öğrencilerin doğum tercihlerini belirlemede algılanan risk veya faydanın $(\mathrm{n}=22)$ en çok ifade edilen ikinci başlık olduğu saptanmıştır. Tüm cevap veren katılımcıların sezaryen doğumu daha riskli bulduğu görülmüş olup, bazı öğrenciler bu düşüncelerini aşağıdaki gibi ifade etmiştir:

“........kendim ve bebeğim için normal doğumun daha sağlıklı olduğunu düşünüyorum. Açıkçası bıçak yarası dikişiydi derken bunların en aza inmesi daha iyi olur" (K5, kadın).

".........bebeğin akciğer fonksiyonlart sezaryen doğuma göre çok daha rahat yerine geliyor. Bebek ayrica anestezik ilaçlara maruz kalmıyor. Annede enfeksiyon riski azallyor. Bu gibi nedenlerden dolay tercihim normal doğumdan yana" (K24, kadin).

"Sezaryende verilen sedasyon, anestezi etkisiyle süt salınımının geç olması, hastanede kalış süresinin uzamasl gibi sebeplerden dolayl normal doğumu isterdim eşim için” (K37, erkek).

Öğrenciler tercihlerini etkileyen bir diğer faktörün ise insan doğasına uygunluk $(n=20)$ olarak ifade etmişlerdir. Normal doğumun insan doğasına daha uygun bulan öğrenciler bu konuda görüşlerini

“.....rahmimde bir canlının yaşlyor olması gibi bir mucize varken onu bu hayatla tanıştırma yöntemim de doğal bir şekilde olmall” (K2, kadın).

"Doğum normal ve doğal bir olaydır. Sezaryen bana yapay bir işlem olarak geliyor ve olayın büyüsünü bozuyor" (K37, erkek), şeklinde ifade etmişlerdir.

Doğum tercihini belirlemede kültürün, gözlem ve duyumların $(n=15)$ yanı sıra ağrı yaşamaya ilişkin düşüncelerin $(n=15)$ de etkili olduğu görülmüştür.

Normal doğum tercihinde bulunan öğrenciler bunun nedenini;

"Normal doğum daha iyi bence çünkü çevremde aldığım duyumlara göre ameliyattan(sezaryeni kastederek) sonra ăgrıları sürekli devam edip hatta bazılarının yıllar sonra pek ağırlık kaldıramadığını ve zorlandığını duydum" (K6, kadın).

“....normal doğumu tercih etmesini isterim eşimden, çünkü çevremdeki insanlar normal doğum dışında yaptığ doğumlardan sonra çok sıkıntı çektiklerini söyledi. Eşimin böyle sıkıntılar çekmesini istemem" (K28, erkek) diye ifade ederken,

Doğum şekli konusunda kararsızlık yaşadığını söyleyen bir öğrenci bu gerekçesini;

"Ailemden en yakınım olanlardan duyduğuma göre normal doğumda sarkmalar oluyormuş hatta bu sarkma ve yırtılmalardan dolayl cinsel haz bile almadıklarını söylüyorlar. Sirf eşleri istiyo diye yaptıklarını söylüyorlar çoğu kez. Sezaryenda vajinal kısımlarda çok deformeler olmuyor sadece karinda ufak bir iz oluyor. Ama yine de bilemiyorum......." (K13, kadın). 
Sezaryen tercih edenler ise;

"Etraftan iyi şeyler duymadım... zor ağrılı dediler o yüzden bende normal doğum istemiyorum" (K14, kadın).

"Sezaryen doğum şeklini isterim. Bir tanıdı̆̆ımızın normal doğumda büyük sıkıntılar yaşadığını duydum ve normal doğumun cesaret gerektiren bir şey olduğunu düşünüyorum" (K15, kadin).

"Daha önce vajinal doğum gördüğüm için o süreçte çok korktum. Çok ă̆rılı olacă̆ını düşündüğüm için de sezaryeni tercih ediyorum" (K31, kadın) diye ifade etmişlerdir.

Ağrı yaşama ile ilgili olarak; gerek normal doğum, gerek sezaryen isteyenler ya da kararsız olan öğrencilerin ağrı yaşamaktan korktukları görülmüştür.

Normal doğumu tercih eden bir öğrenci

"Normal ama suda doğumu isterdim. A $\breve{g r l}$, acı çekmesi daha az" (K, 12 kadın) derken,

Doğum konusunda kararsız olan bir katılımc1;

"Vajinal doğumun acısına katlanmak istemezdim. Sezaryen de zor geliyor..... bazen hayatın çocuksuzda devam edebileceğini düşünüyorum bu yüzden bazen çocuğumun olmasını da istemiyorum" (K, 23 kadın).

Sezaryen doğumu tercih eden bir öğrenci ise;

"Eşim doğum yapacak olsa sezaryen tercih etmesini isterdim. Normal doğumda toparlanma süreci çok daha hizlı olsa da, doğum esnasındaki sancidan dolayl sezaryen doğumu tercih ederdim" (K35, erkek) şeklinde ifade etmiştir.

Çalışmaya katılan öğrencilerin bazıları sezaryenin beden bütünlüğüne zarar verdiğini düşündükleri için $(\mathrm{n}=12)$ vajinal doğumu tercih edeceklerini ifade etmişledir. Öğrenciler bu konudaki fikirlerini

"Sezaryen olup hem kesilip hem neden böyle bir izle yaşayayım ki?" ( K4, kadın).

"Eşimin estetik görüntüsünün bozulmasın istemem, yani bir lekeyle yaşamasın istemiyorum" (K18, erkek).

Doğum şekli konusunda kararsız olan bir katılımcı ise beden bütünlüğü ile ilgili olarak düşüncesini;

"Vajinal doğumda yapilan epizyotomiler korkutucu, sezaryen doğumda ise yine kesiyorlar sizi, karnınızda bir iz onu da istemezdim sonuçta" (K23, kadın) diye belirtmiştir.

Öğrencilerin doğum tercihini belirlemede spiritüel iyilik haline $(n=11)$ ilişsin düşüncelerin de etkili olduğu saptanmıștır. Normal doğum tercih eden katılımcılar spiritüel iyilik hali ile ilgili olarak bu düşüncelerini;

"Insan (kadın) bir çocuk taşlyabiliyorsa, bu onun için mümkünse; onu doğurabilecek içgüdüye, güce ve donanıma da sahip olduğunu düşünüyorum" (K25, kadın).

"Eşimin ilerleyen zamanda doğumunu bir ameliyat olarak değil de gerçek bir doğum olarak hatırlamasını isterim. Ruhani bir boyutu var bence normal doğumun" (K30, erkek), şeklinde belirtmişlerdir.

Doğum tercihini belirlemede, anne-bebek bağlanmasına $(n=9)$ ve doğum anını yaşamaya $(n=8)$ vurgu yapan öğrenciler normal doğum tercihlerine yönelik bu konudaki düşüncelerini
"Bebeğini hemen emzirebiliyorsun ve bebekle arada bağ kuruluyor böylece...”(K16, kadın).

"Anne bebek bă̆ının daha kuvvetli olacă̆ına inaniyorum” (K27, erkek).

"Bebeğimle ilk teması hissetmek için kendimde olmak isterim" (K26, kadın).

"Vajinal ve sezaryen doğum şekillerinin ikisine de şahit oldum ben. Normal doğumda kadın eylemin her aşamasında bebeğine kavuşmak için yaklaştı̆̆ının farkında...hissetiği her sancının bebeğine daha da yaklaştırdı ̆̆ını biliyor...." (K33, kadın), şeklinde ifade etmişlerdir.

\section{TARTISMA VE SONUC}

Doğuma ilişkin algılar bireylere ve kültüre göre farklılık gösterebilmektedir $(3,18,28)$. Yürütülen çalışmada öğrencilerin doğuma ilişkin olumlu algıya sahip oldukları, doğumu sıklıkla heyecan ve mutluluk veren bir olay, yeni bir bireyin dünyaya gelişi, fizyolojik bir süreç, ebeveyn olma süreci olarak düşündükleri belirlenmiştir. Hemşirelik bölümü öğrencileri ile yapılan nitel bir çalışmada da benzer olarak öğrencilerin doğumu genel olarak olumlu algıladığı, doğumun mutlaka yaşanması gereken bir süreç olduğuna, doğum ne kadar zor ve ağrı verici olsa da sonunda bir çocuğa sahip olmanın verdiği mutluluğun vazgeçilmezliğine vurgu yaptıkları belirlenmiştir (3). Doğum korkusu yüksek olan öğrencilerin doğumları korkutucu ve ağrılı olarak tanımlarken, doğum korkusu düşük olan öğrencilerin doğumu doğal bir olay olarak gördükleri belirlenmiștir (20). Aynı zamanda doğuma yönelik bilgi sahibi olmanın da doğuma ilişkin tutumları olumlu yönde etkilediği saptanmıştır (16). Yürütülen çalışmada öğrenciler doğum ile ilgili daha az korku ve endişe ifade etmiş olup, bu sonuç öğrencilerin sağlık bölümünde öğrenim görmeleri ile ilgili olabilir.

Genel olarak gebelik ve doğum çok az düzeyde tıbbi girișim gerektiren fizyolojik bir süreç olsa da bazı kadınların çok yüksek düzeyde korku ve stres yaşadığ 1 bilinmektedir (6). Doğum korkusu gerçekleşmesi beklenen bir doğumla ilgili olarak yaşanan her türlü kaygı ve endişe olarak tanımlanırken (4), özellikle doğum eyleminde ağrı yaşanacağına ilişkin öğrenilmiş bir korku olduğu görülmektedir (19). Doğum korkusu sadece gebe olan, doğum yapan kadınları değil, doğum yapmamış genç bireyleri de etkilemektedir (3). Çalıșmalar sağlık ile ilgili olan ya da olmayan bölümlerde öğrenim gören üniversite öğrencilerinin doğuma ilişkin korku ve endişe yaşadıklarını göstermektedir $(3,17,22,23,27)$. Yapılan bir çalışmada öğrenciler doğumu normal bir yaşam deneyimi olsa da "ac1 verici", "korkutucu", "stresli" ve "profesyonel müdahale gerektiren bir süreç" şeklinde ifade etmişlerdir (17). Çalışma literatürle uyumlu olup öğrencilerin kadınların doğumda acı çektiğini, ağrı yaşadıklarını düşündükleri görülmüş ve doğumla ilgili olası komplikasyonları düşünerek endişe ve korku yaşadıkları belirlenmiștir.

Doğum doğal olduğu kadar aynı zamanda spiritüel bir deneyimdir (29). "Nefes almak", "canlı olmak" olarak adlandırılabilen spiritüalite temelde yaşamı hissetmektir (30). Spiritüalite kişiye hayatının zorlu dönemlerinde destek ve güven sağlayan, yaşam için anlam ve amaç veren bir kavram olarakta tanımlanabilir (31). Bir kadının 
hayatında doğumun en stresli yaşam olaylarından biri olduğu göz önüne alınırsa, özellikle doğum anı bir çok duyguyu barından, beden, zihin ve ruh arasında etkileşim sağlayan spiritüel bir deneyim olarak görülebilir (32). Yürütülen çalışmada öğrencilerin doğumu kutsal bir olay, mucize ve yeni bir başlangıç olarak gördüğü belirlenmiştir. Yapılan bazı çalışmalarda da benzer olarak öğrencilerin doğumu "mucizevi", "en kıymetli varlığa kavuşma", "hayranlık uyandırıcı" ve "inanılmaz" olarak değerlendirdiği görülmüştür $(3,16,17)$.

Doğuma ilişkin algılar doğum tercihlerini etkileyebilmektedir. Üniversite öğrencilerinin doğum tercihlerini belirlemeye yönelik çalışma sonuçları farklı olup, öğrencilerin normal doğumu $(17,24,26,27,33)$ veya sezaryeni (23 ) tercih ettiğini gösteren çalışmaların yanı sıra doğum şekli konusunda kararsızlık yaşandığını gösteren (19) çalışmalar da bulunmaktadır. Buna karşın çalışmalar sağlıkla ilgili bölümlerde öğrenim gören öğrencilerin kendileri veya partnerleri için daha çok normal doğumu tercih ettiklerini göstermektedir $(21,25,26,33)$. Sağlıkla ilgili bölümlerde öğrenim görmek, kadın sağlı̆̆ı ve doğum ile ilgili dersleri almak öğrencilere doğumun fiziksel ve psikososyal yönü hakkında daha gerçekçi bir bakış açısı kazandırabilmektedir $(3,16,33)$. Sekiz OECD ülkesinde 18-25 yaş arasında üniversitede öğrenim gören doğum yapmamış kadınların sezaryen tercihlerinin değerlendirildiği bir çalışmada, katılımcı grubun gebelik ve doğum ile ilgili bilgi düzeyleri arttıkça doğum korkusu ve sezaryen tercihinin azaldığ 1 saptanmıştır (23).

$\mathrm{Bu}$ çalışmada literatürle uyumlu olarak öğrencilerin çoğunluğunun normal doğumu tercih ettiği ve erkek öğrencilerin kadın öğrencilere göre vajinal doğumu daha fazla tercih etme eğiliminde olduğu görülmüştür. Kanadalı ve Brezilyalı üniversite öğrencileri ile yapılan çalışmalarda da benzer olarak kadın öğrencilerin erkek öğrencilere göre normal doğumu daha korku verici ve stresli buldukları, kadınların kendileri için sezaryeni alternatif olarak görebilirken, erkek öğrencilerin vajinal doğumu daha fazla tercih ettikleri saptanmıştır $(17,25)$.

$\mathrm{Bu}$ çalışmada öğrencilerin doğum tercihini belirlemede özellikle doğum şeklinin fiziksel iyilik halini nasıl etkilediğine ve normal doğumun avantajlarına değindikleri, algılanan risk-yarar kısmında sezaryene bağlı oluşabilecek komplikasyonlara vurgu yaptıkları, normal doğumu insan doğasına en uygun doğum şekli olarak gördükleri belirlenmiştir. Sezaryen doğum gerekli olduğunda anne ve bebek için yaşam kurtarıcı obstetrik bir girişim olmasına karşın; maternal mortalite ve morbidite riskini artırdığı ve maliyetinin yüksek olduğu bilinmektedir (9). Yürütülen çalışmada öğrencilerin sezaryenin olumsuz sonuçlarının farkında olması bu anlamda olumlu olarak değerlendirilebilir. Yapılan çalışmalarda da çalışma bulgusu ile uyumlu olarak normal doğum tercihinde bulunanların normal doğumu doğal bir süreç olarak gördükleri, doğum sonu iyileşme sürecinin hızlı olduğunu ve anne ve fetus için daha az risk taşıdığını düşündükleri görülmüştür $(19,22,24,25,27,28,33)$.

Sağlıklı ilgili konularda bilgi sahibi olmak doğum tercihlerini belirlemede etkili olsa da aile üyeleri ve sosyal çevreden duyulan doğum öykülerinin, medyanın ve doğum ile ilgili yaşantıların da bu tercihleri etkilediği bilinmektedir $(18,19,26,34)$. Doğumla ilgili çevreden duyulan abartılı ve olumsuz deneyimler, olumsuz doğum algısını pekiştirirken, anksiyeteyi ve obstetrik komplikasyon beklentisini artırmaktadır (20). Bu çalışmada da öğrenciler benzer olarak aile büyüklerinin doğuma ilişkin olumsuz anlatımlarından ve gözlemledikleri doğumlardan etkilenmiştir. $\mathrm{Bu}$ bulgu doğuma ilişkin alg1 ve doğum tercihlerini değerlendirirken kültürün, sosyal çevrenin ve geçmiş deneyimlerin göz ardı edilmemesi gerektiğini düşündürmektedir.

Doğum ağrıll, sonucu kesin olarak önceden tahmin edilemeyen, belirsizliklerin olduğu bir süreç olup, kadınların doğum korkusu yaşaması bir dereceye kadar normaldir (35). Bununla birlikte doğumda ağrı yaşamaya yönelik endişeler doğum tercihini etkilemektedir (26). Özellikle normal doğumun ağrılı, dayanılmaz ve korkutucu olduğuna yönelik algının, kadınların kendilerinin de olumsuz deneyim yaşayacağını düşündürerek sezaryene yönlendirebilmektedir $(19,21,27)$. Ağrı normal doğumda travay sürecinde, sezaryende doğum sonu dönemde daha fazla yaşansa da, travayda yaşanan ağrı bireyler için daha korkutucu olabilmektedir (28). Yürütülen çalışmada öğrencilerin doğum tercihini belirlemede ağrı ile ilgili görüş bildirme sıklığı daha düşük olsa da, doğum sürecinde yaşanan ağrıya ilişkin endişelerin sezaryen tercihinde belirleyici olduğu görülmektedir. Çalışma bulgusu literatürle uyumludur. Öğrenciler için doğumda ağrı kontrolü önemli olup yapılan bir çalışmada ağrıdan kaçınmak için ögrencilerin \%73,9'unun normal doğum sirasında epidural anestezi yapılabileceğini düşündüğü saptanmıştır (27).

Yapılan çalışmada doğum şekli tercihinde beden bütünlüğüne vurgu yapan öğrencilerin çoğu sezaryen ile ilişkili olarak yapılan insizyonların hem fiziksel hem de estetik olarak beden imgesini etkileyeceğini, bu nedenle normal doğumu tercih ettiklerini ifade etmişlerdir. Öğrencilerin içinde bulunduğu yaş dönemi gözönüne alındığında beden imajı ile ilgili estetik kaygılar yaşamalarının doğal olduğu düşünülebilir. Yürütülen çalışmaya benzer olarak üniversite öğrencileri ile yapılan bir başka çalışmada da öğrencilerin sezaryen ameliyatına bağlı skar dokusu oluşmasını istemedikleri için normal doğumu tercih ettikleri belirlenmiştir (19). Sağlık bölümlerinde öğrenim gören öğrenciler ile yapılan bir diğer çalışmada ise normal doğum tercihi ile sezaryenin beden bütünlügüne daha fazla zarar vereceğini düşünme arasında ilişki olduğu belirlenmiştir (33). Bu bulguların aksine Doğaner ve arkadaşlarının (27) ebe, hemşire ve tıp fakültesi öğrencileri ile yaptığ daha çok normal doğuma bağlı oluşan yırtıklardan endişe ettiği belirlenmiştir. Çalışma bulgularındaki fark Doğaner ve arkadaşlarının çalışmasının sadece kadın doğum dersini almış öğrenciler ile yapılırken, yürütülen çalışmanın kadın doğum dersi almayan öğrencileri de kapsaması ve yapılan gözlemler ile ilgili olabilir.

Doğum tercihini belirlemede tıbbi endikasyonların yanında sosyal ve psikolojik faktörler de etkilidir $(26,33)$. Bununla birlikte doğumun psikolojik ve spiritüel yönü göz ardı edilebilmektedir (24). Yürütülen çalışmada öğrenciler normal doğum tercihlerini belirleyen faktörleri açıklarken özellikle kadın öğrenciler doğum ile ilgili psiko-sosyal ve spiritüel faktörlere daha fazla vurgu 
yapmıştır. Öğrenciler doğum anının, bebeğe kavuşma anının hazzını yaşamak için normal doğumun önemli olduğu ifade etmiştir. Stoll ve arkadaşlarının (24) üniversite öğrencileri ile yaptığı çalışmada da yürütülen çalışmaya benzer olarak yalnızca kadın öğrenciler normal doğumun bebekle kurulan bağ güçlendiren, dönüștürücü bir kadın deneyimi olduğunu söylemişlerdir. Yapılan bazı çalışmalarda da kadın öğrenciler normal doğumda anneliğin daha çok hissedilebileceğini (19), normal doğumun kadınları güçlendirici bir deneyim olduğunu ifade etmişlerdir (16). Doğum sürecini kadınların daha aktif yaşadıkları göz önüne alındığında annelik duygusu ile ilgili ifadelerin daha çok kadın öğrenciler tarafından dile getirilmesi doğaldır. Aynı zamanda ülkemizde gerek ataerkil kültürel yaklaşımlar gerekse hastane politikaları nedeniyle erkekler doğum sürecine yeterince dahil olamamaktadır. Bu bağlamda erkek öğrencilerin doğumun psikososyal ve spiritüel yönüne daha az vurgu yapmış olabileceği düşünülmüştür.

Öğrencilerinin doğuma ilişkin algılarının olumlu olduğu ve normal doğumu tercih ettikleri belirlenmiştir. Doğum tercihini belirlemede öğrencilerin daha çok fiziksel iyi oluş, doğum şekli ile ilgili riskler ve faydalar ile doğumun insan doğasına uygunluğuna değindikleri görülmüştür. Doğum tercihini belirlemede etkili görünen psikolojik ve spritüel iyilik hali ile düşünce ve duyguların ise daha fazla kadın öğrenciler tarafından dile getirildiği saptanmıştır. Öğrenciler genel olarak olumlu algıya sahip olsalar da, gözlem ve duyumlardan olumsuz etkilendikleri göz önünde bulundurularak aile öyküsü, medyanın etkileri daha ayrıntılı değerlendirilmeli, doğuma ilişkin klinik deneyimleri ve yaşadıkları güçlükler tartışılarak baş etmeleri güçlendirilmelidir. Ayrıca mevcut eğitim müfredatlarında öğrencilerin gebelik ve doğum hakkında bilgi gereksinimlerini, endişelerini yansıtan, doğum ve spiritüalite arasındaki ilişkiye vurgu yapan düzenlemeler yapılmasının faydalı olacağı düşünülmektedir.

\section{TEŞEKKÜR}

Araştırmaya katılan tüm öğrencilere katkılarından dolayı teşekkür ederim.

Yazarların Katkıları: Fikir/Kavram: N.Ç.B.; Tasarım: N.Ç.B.; Veri Toplama ve/veya İşleme: N.Ç.B.; Analiz ve/veya Yorum: N.Ç.B.; Literatür Taraması: N.Ç.B.; Makale Yazımı: N.Ç.B.; Eleştirel İnceleme: N.Ç.B.

\section{KAYNAKLAR}

1. Nilsson C, Hessmen E, Sjöblom H, Dencker A, Jangsten E, Mollberg $M$, et al. Definitions, measurements and prevalence of fear of childbirth: a systematic review. BMC Pregnancy and Childbirth. 2018; 18(28): 2-15. doi: 10.1186/s12884-018-1659-7.

2. Körükçü O, Deliktaş A, Aydın R, Kabukcuoğlu K. Investigation of the relationship between the psychosocial health status and fear of childbirth in healthy pregnancies. Clinicial and Experimental Health Sciences. 2017; 7(4): 152-8. doi: 10.5152/clinexphealthsci.2017.359.

3. Kapısız Ö, Karaca A, Özkan SF, Savaş HG. Hemşirelik öğrencilerinin doğum algısı. Düzce
Üniversitesi Sağlık Bilimleri Enstitüsü Dergisi. 2017; 7(3): 156-60.

4. Lukasse M, Schei B, Ryding EL. Prevalence and associated factors of fear of childbirth in six European countries. Sex Reprod Healthc. 2014; 5(3): 99-106. doi: 10.1016/j.srhc.2014.06.007

5. Stoll K, Hauck Y, Downe S, Edmonds J, Gross MM, Malott A, et al. Cross-cultural development and psychometric evaluation of a measure to assess fear of childbirth prior to pregnancy. Sex Reprod Healthc. 2016; 8: 49-54. doi: 10.1016/j.srhc.2016.02.004.

6. Jha P, Larsson M, Christensson K, Svanberg AS. Fear of childbirth and depressive symptoms among postnatal women: A cross-sectional survey from Chhattisgarh, India. Women and Birth. 2018; 31(2): 122-33. doi: 10.1016/j.wombi.2017.07.003.

7. Markowska US, Żur A, Skrzypulec-Plinta V, Machura M, Czajkowska M. Causes and frequency of tocophobia - own experiences. Ginekologia Polska. 2017; 88(5): 239-43. doi: 10.5603/GP.a2017.0045.

8. Coşkuner Potur D, Mamuk R, Şahin N H, Demirci N, Hamlac1 Y. Association between fear of childbirth and maternal acceptance of pregnancy. Int Nurs Rev. 2017; 64(4): 579-83. doi: 10.1111/inr.12378.

9. World Health Organization (WHO). WHO Statement on Ceserean Section Rates 2015 [Internet]. Geneva: [Updated: 2020 May 16, Cited: 2020 Mar 15] Available from: https://apps.who.int/iris/bitstream/handle/10665/16144 2/WHO_RHR_15.02_eng.pdf;jsessionid=BD12DF39 F0021D3F4487F239597CB12E? sequence $=1$.

10. Organisation for Economic Cooperation and Development (OECD) iLibrary. Health at a Glance 2017: OECD Indicators [Internet]. Paris: [Updated: 2020 May 16, Cited: 2020 Mar 22] Available from: http://dx.doi.org/10.1787/health_glance-2017-en.

11. Hacettepe Üniversitesi Nüfus Etütleri Enstitüsü [Internet]. Ankara: Hacettepe Üniversitesi; 2018 Türkiye Nüfus ve Sağlık Araştırması (2018 TNSA). [Son güncelleme tarihi: Kasım 2019; Erişim tarihi: 18 Mart 2020] Erişim adresi: http://www.hips.hacettepe.edu.tr/tnsa2018/rapor/TNS A2018_ana_Rapor.pdf.

12. Karabel $M$, Demirbaş $M$, İnci $M$. Türkiye'de ve Dünya'da değişen sezaryen sıklığ 1 ve olası nedenleri. Sakarya Tıp Dergisi. 2017; 7(4): 158-63. doi: 10.31832/smj.368600.

13. Haines HM, Rubertsson C, Pallant JF, Hildingsson I. The influence of women's fear, attitudes and beliefs of childbirth on mode and experience of birth. BMC Pregnancy and Childbirth. 2012; 55: 1-14. doi: 10.1186/1471-2393-12-55.

14. Atan ŞÜ, Duran ET, Kavlak O, Donmez S, Sevil U. Spontaneous vaginal delivery or caesarean section? What do Turkish women think? International Journal of Nursing Practice. 2013; 19(1): 1-7. doi: 10.1111/ijn.12029.

15. Karabulutlu Ö. Kadınların doğum şekli tercihlerini etkileyen faktörler. İ.Ü.F.N Hem Derg. 2012; 20(3): 210-8.

16. Cleeton ER. Attitudes and beliefs about childbirth among college students: Results of an educational 
intervention. Birth. 2001; 28(3): 192-200. doi: 10.1046/j.1523-536x.2001.00192.x.

17. Palumbo CS, Hsu R, Tomkinson J, Klein MC. Preuniversity students' attitudes and beliefs about childbirth: Implications for reproductive health and maternity care. Canadian Journal of Midwifery Research and Practice. 2012; 11(2): 27-37.

18. Stoll K, Hall W, Janssen P, Carty E. Why are young Canadians afraid of birth? A survey study of childbirth fear and birth preferences among Canadian University students. Midwifery. 2014; 30(2): 220-6. doi: 10.1016/j.midw.2013.07.017.

19. Kadığlu M, Şahin N. Üniversite öğrencilerinin doğum şekline yönelik görüșleri, tercihleri ve etkileyen faktörler. KASHED. 2019; 5(2): 43-69.

20. Stoll K, Hall WH. Attitudes and preferences of young women with low and high fear of childbirth. Qualitative Health Research. 2014; 23(11): 1495-505. doi: 10.1177/1049732313507501.

21. Amanak K, Balkaya NA. Ebelik bölümü öğrencilerinin doğal doğuma yönelik bilgi ve düşünceleri. Gümüşhane Üniversitesi Sağlık Bilimleri Dergisi. 2013; 2(2): 169-92.

22. Watanabe T, Knobel R, Suchard G, Franco MJ, d'Orsi E, Consonni EB, et al. Medical students' personal choice for mode of delivery in Santa Catarina, Brazil: A cross-sectional, quantitative study. BMC Med Education. 2012; 12(1): 1-9. doi: 10.1186/1472-692012-57.

23. Stoll KH, Hauck YL, Downe S, Payne D, Hall WA, International Childbirth Attitudes - Prior to Pregnancy (ICAPP) Study Team. Preference for cesarean section in young nulligravid women in eight OECD countries and implications for reproductive health education. Reproductive Health. 2017; 14(116): 1-9. doi: 10.1186/s12978-017-0354-X.

24. Stoll K, Fairbrother N, Carty E, Jordan N, Miceli C, Vostrcil Y, et al. "It's all the rage these days": University students' attitudes toward vaginal and cesarean birth. Birth. 2009; 36(2): 133-40. doi: 10.1111/j.1523-536x.2009.00310.x.

25. Knobel R, Takemoto ML, Andreucci CB, Docusse P, McKinley DW, Amaral E. Factors associated with preference for vaginal birth among undergraduate students from southern Brazil. Birth. 2016; 43(3): 2637. doi: $10.1111 /$ birt.12235.

26. Aksu H, Özsoy S. Ebelik ve hemşirelik öğrencilerinin doğum şekli tercihleri ve etkileyen faktörler. Sağlık Bilimleri Dergisi. 2015; 24(1): 44-8.

27. Doğaner G, Doğaner A, Duran Ö, Tuna M, Tezcan Ş, Turan G. Sağlık bilimlerinde okuyan öğrencilerin doğum şekli tercihlerine yönelik düşüncelerinin belirlenmesi. TJOD. 2013; 10(1): 31-6. doi: 10.5505/tjod.2013.57625.

28. Duran ET, Atan ŞÜ. Kadınların sezaryen/vajinal doğuma ilişkin bakış açılarının kalitatif analizi. Genel Tip Derg. 2011; 21(3): 83-8.

29. Crowther S, Hall J. Spirituality and spiritual care in and around childbirth. Women and Birth. 2015; 28(2): 173-8. doi: 10.1016/j.wombi.2015.01.001.

30. Çınar F, Aslan FE. Spiritüalizm ve hemşirelik: Yoğun bakım hastalarında spiritüel bakımın önemi.
Hemşirelik Akademik Araştırma Dergisi. 2017; 3(1): 37-42. doi: 10.5222/jaren.2017.037.

31. Hill PC, Pargament KI. Advances in the conceptualization and measurement of religion and spirituality. Implications for physical and mental health research. American Psychologist. 2003; 58(1): 64-74. doi: 10.1037/0003-066x.58.1.64.

32. Taghizdeh Z, Ebadi A, Dehghani M, Gharacheh M, Yadollahi P. A time for psycho-spiritual transcendence: The experiences of Iranian women of pain during childbirth. Women Birth. 2017; 30(6): 491-6. doi: 10.1016/j.wombi.2017.04.010.

33. Tektaş E, Bozkurt G, Ergin E, Sezgin S. Sağlık Bilimleri Fakültesi öğrencilerinin doğum şekli tercihleri ve etkileyen faktörler. Cukurova Med J. 2018; 43(Suppl 1): 63-9. doi: 10.17826/cumj.412655.

34. Young K, Miller YD. Keeping it natural: Does persuasive magazine content have an effect on young women's intentions for birth? Women Health. 2015; 55(4): 447-66. doi: 10.1080/03630242.2015.1022690.

35. Madhavanprabhakaran GK, D'Souza MS, Nairy KS. Prevalence of pregnancy anxiety and associated factors. International Journal of Africa Nursing Sciences. 2015; 3: 1-7. doi: 10.1016/j.ijans.2015.06.002. 